\title{
The Implementation of Nonprofit Principles toward Foundation Property Management
}

\author{
Desi Alinda Subiyanto ${ }^{1}$, Albertus Sentot Sudarwanto ${ }^{2}$ \\ ${ }^{1}$ Master Student of Notary, Sebelas Maret University, Surakarta, Indonesia \\ ${ }^{2}$ Postgraduate of Notary, Sebelas Maret University, Surakarta, Indonesia \\ desialsubiyanto@yahoo.com
}

\begin{abstract}
Foundation as a legal entity means that foundation as a legal subject has a property that is separated by civil law so that the foundation property is useful to achieve the goals and objectives of the foundation and not for profit. The nonprofit principle means that the existing capital is not processed for profit, but rather activities that benefit the community. Foundation property, whether in the form of money, goods or other properties obtained by a foundation under the Foundation Law, is prohibited from being transferred or distributed directly in the form of salaries, wages, or honoraria or other forms that can be valued in cash with Governing Board, Executive Board, and Supervisory Board. The implementation of the foundation's principles in managing the foundation property must be adjusted to the condition of the foundation set out in the Statutes and Bylaws based on the foundation's principles which are Transparency, Accountability, and Publicity.
\end{abstract}

Keywords

Nonprofit principles,

foundation properties

foundation

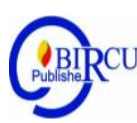

\section{Introduction}

Foundation is a legal entity consisting of properties that are separated and destined to achieve certain goals and objectives. Foundation as a legal entity means a foundation as a legal subject has a property that is separated by civil law so that the foundation property is useful to achieve the goals and objectives of the foundation and not for profit. Foundation has the specific aims and objectives in the social, religious and humanitarian fields that do not have members and can take legal action by separating a foundation property from its founder, but at present, there are still some foundations that do not apply the foundation's principles in managing the foundation property so that the goals of the foundation be looking for profit and not doing social business.

Foundation is a nonprofit-oriented legal entity, which is generally established by one or more people or is established based on a will so that there is a separation of properties from its founder and aims in the social field. Based on the principle of non-profit oriented, foundation is not looking for profits, but capital obtained from social funds aimed at community use, in Article 5 paragraph (1) of Law Number 28 of 2004 concerning Amendments to Law Number 16 of 2001 Regarding the Foundation (abbreviated as Law R1 28 of 2004 concerning the Foundation) stated that the foundation's property in the form of money, goods, and other properties obtained by the Foundation under this Law, is prohibited from being transferred or distributed directly or indirectly, whether in the form of salary, wages, or honorarium, or other forms that can be valued in cash to the Governing Board, Executive Board, and Supervisory Board. 
The exception for administrators get wages, salaries or honoraria specified in the Articles of Association that have been adjusted to the wealth of the Foundation, in the case of Executive Board or Manager of Foundation:

- It is not the founder of the Foundation and is not affiliated with the Founder, Executive Board or Supervisory Board;

- Implement direct and full management of the Foundation.

The non-profit principle means that the existing capital is not processed for profit, but rather activities that benefit the community. This is regulated in Law No. 28/2004 concerning Foundation strictly regulates that the establishment of foundations are not for profit, but as referred to in Article 1 number (1) concerning the definition of foundation, it is the aim of foundations in the social, religious and humanitarian fields. Based on Article 3 paragraph (2) states that the foundation must not share the results of business activities with the Governing Board, Executive Board, and Supervisory Board. The three organs of the foundation may not seek profit in a foundation institution.

Foundation property based on Article 5 paragraph (1) is in the form of money, goods or other properties obtained by a foundation under the Foundation Law, is prohibited from being transferred or distributed directly in the form of salary, wages, or honorarium or other forms that can be valued in money to the Governing Board, Executive Board and Supervisory Board. Therefore, the foundation is not known as profit sharing and if the foundation is dispersed, the remaining property of the foundation cannot be returned to the founder but it must be transferred to the foundation that has the same goal or returned to the state.

Based on the above description, the researcher is interested in discussing "How to Implement the Nonprofit Principles to the Foundation Property Management".

\section{Review of Literature}

\subsection{Legal Entity Theory}

Some theories about legal entities, namely:

a. Fiction Theory

The pioneer of this theory was a German scholar, Fredrich Carl Von Savigny, he stated that only humans have the will, the legal entity is actually not there, many people turn on their shadows to explain something and occur because humans make based on the law or in other words, is made by law or person ficta. According to this theory, wealth is managed with a specific purpose. In short, what is called the rights of legal entities are actually rights without legal subjects. Therefore, wealth that is bound by a goal is as a substitute.

\section{b. Organ Theory}

This theory emerged as a reaction from the fiction theory of Von Savigny above, this theory was put forward by Otto Von Gierke, and he stated that legal entity is like a human being, becoming really existed in the association of law. Legal entity is a body that forms its will with the tools or organs of the body, what is decided by the instrument is the will of the legal entity itself. Therefore, legal entity is actually evident in its quality as a legal subject.

\section{c. Properties Due to Position Theory (Leer van het ambfilijk vermogen)}

This theory was proposed by Holder and Binder. This theory mentioned that legal entity is an independent asset, which is owned by the legal entity but by its management and because of his position, he/she is given the task of managing the properties. 
d. Theory of Joint Wealth (Propriete Collecthive)

This theory was taught by Molegraf, Marcel Planiol, and Rudolf Von Ihering. This theory holds that legal entity is in the interest of all its members. It is an abstraction legal entity and not an organization. In essence, the rights and obligations of legal entities are the rights and obligations of members together. They are jointly responsible, the properties of the agency are shared properties. The members come together as one entity and form personally called a legal entity.

\section{e. Properties Aims Theory}

This theory was proposed by A Brinz and Van der Heidjen. This theory mentioned that only humans can become legal subjects because legal entity is not legal subjects and the rights granted to a legal entity are essentially rights with no legal subject.

\section{f. Juridical Properties Theory}

This theory was a refinement of organ theory. This theory was put forward by E.M. Majers and Paul Scholten. According to Majers, legal entity cannot be touched, not imaginary, but a juridical reality, but a simple theory of reality means to emphasize that in equating human beings with legal entity is limited to the legal field. The division of legal entity based on to its field, and based on the nature of the legal entity is divided into 2 (two), namely:

- Corporate

- Foundation.

According to Utrecht, corporate is a combination of people who in legal association act together as a legal subject themselves. Corporate is a legal entity whose members have their own rights and obligations separate from the rights and obligations of their respective members. While foundation is any property that does not constitute the property of a person or body property and which is given a specific purpose. In legal association, the foundation acts as a supporter of its own rights and obligations.

The fundamental difference between foundation and corporate is that they become legal entities without members, but the foundation has an administrator who manages the property and organizes its goals.

\subsection{Review of the Foundation}

a. Understanding the Foundation

The foundation was known since the days of the Dutch East Indies until today by the people of Indonesia. Foundation grows, lives and develops as institutionalized non-profit activities. Legal entity recognition for the Foundation in Indonesia was initially based only on customs and jurisprudence because no provisions were governing it. But in practice, the Foundation is a body that runs a business that engages in all kinds of business entities, both those engaged in non-commercial businesses and those that are indirectly commercial. In Dutch, foundation is called Stichting, which can be found in several provisions of the Civil Code including Article 367, Article 899, Article 900 and Article 1680. In applicable legal practice, the foundation must be established with a notarial deed as a condition for the formation of the foundation so that there is a separation of assets that cannot be controlled by the founder anymore.

Based on customary law, the characteristics of a foundation can be stated as law as follows: 
- The existence of foundations as legal entities in Indonesia has not been based on applicable laws and regulations;

- The recognition of foundations as a legal entity has a strictly legal basis in contrast to PT (Private Company/Limited Liabilty Company), Cooperate and other legal entities;

- Foundation is formed by separating the founder's personal property for non-profit purposes, for religious, social-religious, humanitarian and other purposes;

- Foundation is established by notarial deed or by decree of the official concerned with the founding of the foundation:

- The foundation does not have members and is not owned by anyone, but has a manager or organ to realize the goals of the foundation;

- The foundation has an independent position, as a result of the existence of separate property and personal property of the founder or its management and has its own goals different or separated from the personal goals of the founder or management;

- Foundation is recognized as legal entities as persons recognized as independent legal subjects who can carry rights and obligations, is established by deed and registered;

- The foundation can be dissolved by the Court if the purpose of the foundation is against the law and can be liquidated or declared bankrupt.

\section{b. Foundation according to the Law}

The law governing the Foundation was first passed on August 6, 2001, namely the Law of the Republic of Indonesia Number 16 of 2001. Before the birth of the Foundation Law, the establishment of the Foundation in Indonesia was based on custom, doctrine, and jurisprudence. This was explained that:

- Habit IS human actions that are carried out repeatedly about matters of behavior that are accepted by a society that is always carried out by other people in such a way so that it assumes that it must indeed be so;

- Doctrine is the decision of the previous judge which is used as material for consideration by the next judge in making decisions;

- Jurisprudence is the opinion of a prominent legal scholar whose influence on the judge in making his decision.

The Law of the Republic of Indonesia Number 16 of 2001 concerning the Foundation is expected to be able to overcome various problems regarding the foundation, but in its development, the Act has not been able to meet the needs and development of law in the community. Therefore, a change law is formed which is expected to guarantee legal certainty and order, as well as provide a good understanding of the community.

The adoption of the Law of the Republic of Indonesia Number 28 of 2004 concerning Amendments to the Law of the Republic of Indonesia Number 16 of 2001 concerning this Foundation, all matters regarding foundations and the understanding of foundations are expected to be clear. While, based on Article 1 paragraph (1), the foundation is a legal entity consisting of assets separated and designated to achieve certain objectives in the social, religious and humanitarian fields and does not have members. From the description above confirms that the status of the foundation is a legal entity and provides legal certainty in the community. The position of the foundation as a legal entity through a system or procedure of endorsement from the government (Ministry of Law and Human Rights of the Republic of Indonesia) based on Article 11 paragraph (1), namely the foundation obtained legal entity status after the deed of establishment of the Foundation as referred to in Article 9 paragraph (2) obtain authorization from the Minister. 
Fred BG Tumbuan examined that the foundation as intended by Law Number 16 of 2001 on Foundations, it stated that unlike humans who can act on their own, the foundation as a legal entity is an independent legal subject that can only do deeds not by human intermediaries as their representatives namely through organs foundation to achieve the goals of the foundation's establishment.

\section{c. Foundation Legal Principles}

Some of the Principles in the Foundation according to the Law of the Republic of Indonesia Number 16 of 2001 concerning Foundations and the Republic of Indonesia Law Number 28 of 2004, include:

- Foundations as non-profit institutions;

- Founder of the Foundation declaratively;

- Formally the establishment of the foundation must be with a notarial deed

- The foundation as a legal entity after obtaining authorization from the Minister;

- Legal actions were undertaken by the Management on behalf of the Foundation before the Foundation obtains a legal entity are the responsibility of the management in a joint responsibility;

- The Foundation can establish or participate in business activities to achieve its aims and objectives and does not conflict with public order, decency and/or legislation in force, the participation is at most $25 \%$ of the value of the entire properties of the Foundation

- Foundation property is prohibited from being transferred or distributed to Foundation Organs, employees or other parties that have direct or indirect interests in the Foundation or other forms that can be valued in money;

- Foundation Managers receive salaries, wages or honoraria determined by the Governing Board according to the Foundation's property capabilities, with the following limitations:

○ The management concerned is not the founder of the foundation and is not affiliated with the Foundation's organs;

o Implement direct and full management of the Foundation.

- The aims and objectives of the foundation cannot be changed;

- The Statutes of the Foundation can be changed based on the decision of the Governing Board if it is attended by $2 / 3$ of the number of members of the Governing Board;

- There is no concurrent positions in the organ of the Foundation.

- Positions in the Foundation (as Governing Board, Supervisory Board, Executive Board personally/individually) or not in certain capacity positions;

- If there is an ultra vis or act against the law, the Foundation board members are personally responsible or for the loss, both towards the Foundation and third parties;

- If the foundation is liquidated, the remaining liquidation proceeds are handed over to other foundations that have the same aims and objectives as the dissolved foundation if this matter is regulated in the Law on the Legal Entity, if not done so, the remaining assets shall be handed over to the state and its use is carried out in accordance with the aims and objectives of the foundation;

- Each Foundation organ that transfers or directly or indirectly distributes the Foundation's assets to the Foundation's organs, employees or other parties having a Foundation interest shall be sentenced to a maximum imprisonment of 5 (five) years 
and convicted with additional crimes in the form of obligation to return money, goods or wealth of the Foundation transferred or distributed;

- Foundations cannot be transferred (inherited/bought/sold).

d. Aims and Objectives of the Foundation

In article 1 number 1 of RI Law Number 16 of 2001 Concerning the Foundation confirms that the Foundation's objectives are only 3 (three) sectors, namely:

- Social Sector

Foundation in the social sector is based on their form and type which is engaged in formal social institutions, primary and secondary educational institutions. This is the type of foundation that will be in the form of a nursing home, polyclinic, hospital, orphanage, research and laboratory which can later support the movement and development of science.

- Humanitarian Sector

This foundation which is active in the social sector is a foundation that will provide assistance and care for various humanitarian actions. Such as assisting refugees, victims of various natural disasters, the poor, the homeless, the construction of funeral homes and open houses so that they can become an organization that preserves and provides protection to those in need.

- Religious Sector

The foundation will manage various houses of worship, madrassas, several Islamic boarding schools, and other religious-related places.

\section{Discussion}

Based on Article 2 of the Foundation Law, foundation has organs that consist of the Governing Board, Executive Board, and Supervisory Board. There are only 3 (three) foundation organs, these are intended that there is no other organs formed by the founder that is not based on the Foundation Law. The following are the responsibilities and duties of the authority of each foundation organ:

\subsection{Governing Board}

In Article 28 of the Law of the Republic of Indonesia Number 16 of 2001 concerning Foundations, the authorities of the Governing Board are:

a. Governing Board is foundation organs that have authority to not left to the Executive Board or Supervisory Board by this Law or Statutes;

b. The authority referred to in paragraph (1) includes:

- Decision regarding amendments to the Statutes;

- Appointment and dismissal of members of the Executive Board and Supervisory Board members;

- Appropriate general policies of the Foundation based on the Statutes of the Foundation;

- Approval of the Foundation's annual work program and draft budget; and

- Decision on the merger or dissolution of the Foundation. 


\subsection{Executive Board}

In Article 31 paragraph (1) of the Foundation Law, it does not explain the authority of the Executive Board, but the Executive Board in charge. Executive Board is a foundation organ that carries out the management of the Foundation only for the benefit of the foundation, the Executive Board while carrying out the duties which are considered by the Governing Board to be detrimental to the Foundation based on the decision of the Governing Board meeting, it can be dismissed before the management period ends.

\subsection{Supervisory Board}

In Article 40 paragraph (1) of the Foundation Law, it does not stipulate the Supervisory Board authority, but the duties of the Supervisory Board. Supervisory Board is the organ of the Foundation that is in charge of conducting supervision and giving advice to the Executive Board in carrying out Foundation activities.

The implementation of the foundation's principles in managing the property of the foundation consists of 2 (two) models of the foundation, namely non-operational foundations, which means that foundation is engaged in the social field, but this foundation is not directly active in the relevant social fields, but their activities are merely collecting funds through alms to generate fundraising which will be donated in social activities organized by other parties. While operational foundation is foundations that are directly engaged in organizing their own social activities such as organizing schools, hospitals, orphanages, and other social activities.

Based on Law No. 28/2004 concerning the distribution of foundation property is permitted only to managers who are not the founder of the foundation, are not affiliated with the Governing Board, Executive Board, and Supervisory Board who carry out the foundation's management directly. According to Mansaray (2019) Performance management practice is concern with the assessment and development of people at work. The practice has developed to be one of the most important features of today's operative organizations. The distribution of property must be adjusted to the condition of the foundations set out in the Statutes and Bylaws of each foundation, thus, ensuring certainty and law order so that the foundation functions in accordance with the aims and objectives based on the foundation's principles of openness and accountability.

\section{Conclusion}

Law Number 28 of 2004 concerning Foundations regulating the property of foundations is prohibited to be transferred or distributed directly or indirectly in the form of salaries, wages or salaries in other forms that can be valued in cash to the Governing Board, Executive Board, and Supervisory Board. Giving foundation property is only to the executor of daily activities that are not affiliated with the founder, Governing Board and Supervisory Board as well as direct and full management based on the foundation's ability that has been set in the Statutes and Bylaws in accordance with the foundation's principles, i.e. Transparency, Accountability and Publicity. 


\section{References}

Mansaray, H. S. (2019). The Role of Human Resource Management in Employee Motivation and Performance-An Overview. Budapest International Research and Critics Institute (BIRCI) Journal, 183-194.

Murjiyanto, (2011), Badan Hukum Yayasan, Yogyakarta: Liberty Yogyakarta.

Paul L. Davies, Gowet. (1997). Principles of Modern Company Law. London: Sweet Maxwell.

Rudhi Prasetya, (2012), Yayasan Dalam Teori dan Praktik, Jakarta: Sinar Grafika.

Rochmat Soemitra, (1993). Hukum Perseroan Terbatas, Yayasan dan Wakaf. Bandung: PT. Eresco.

Undang-undang Republik Indonesia Nomor 16 Tahun 2001 Tentang Yayasan.

Undang-undang Republik Indonesia Nomor 28 Tahun 2004 Tentang Perubahan atas Undang undang Republik Indonesia Nomor 16 Tahun 2001 Tentang Yayasan. 